
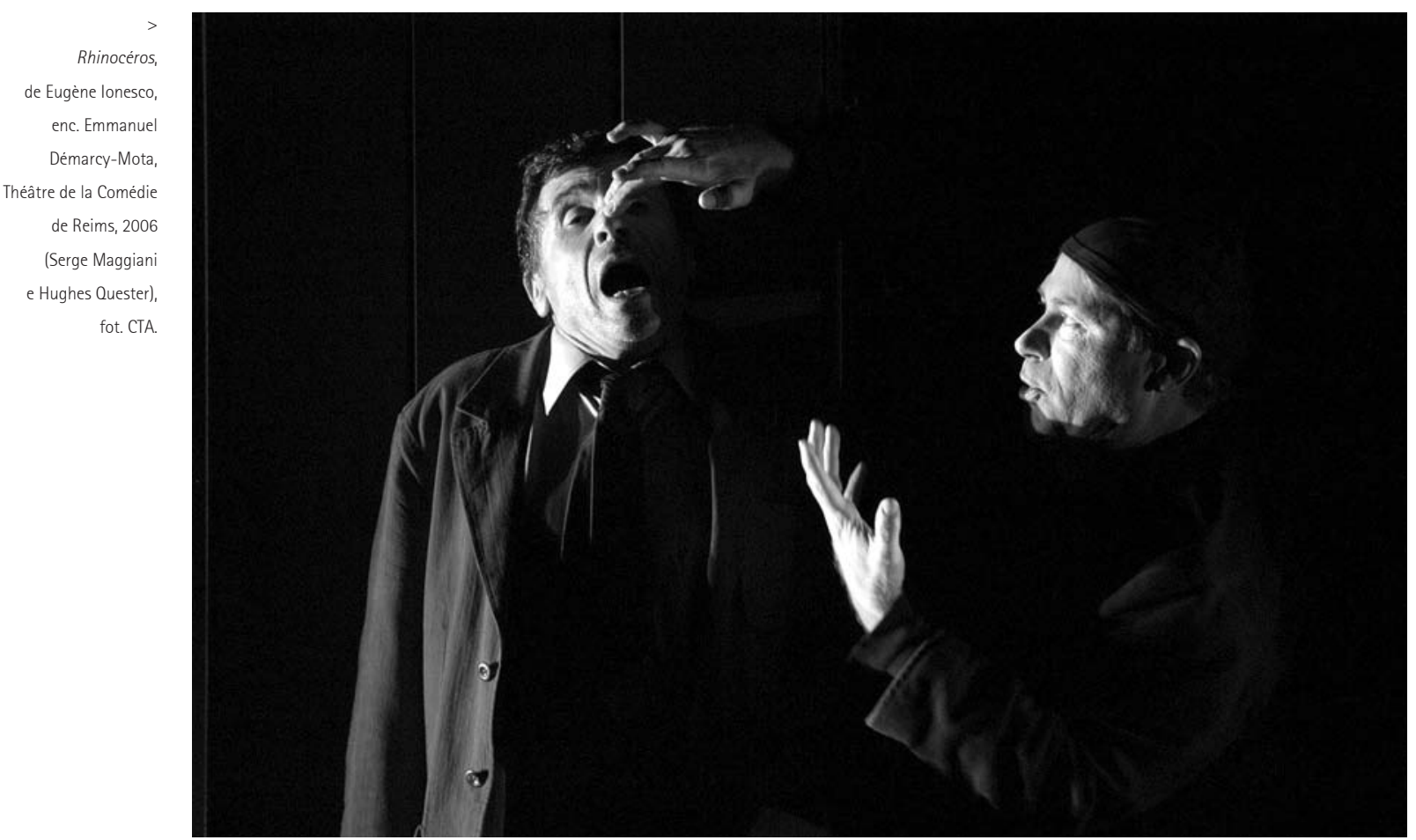

\title{
Revisitar lonesco Um novo figurino para a rinocerite
}

\section{Maria João Brilhante}

Titulo: Rhinocéros (1958). Autor: Eugene lonesco. Encenação: Emannuel Démarcy-Mota. Produção: Comédie de Reims. Apresentações em Portugal: Rivoli Teatro Municipal, Porto, 7-8 de Julho de 2006; Teatro Nacional D. Maria II, Lisboa, 13-14 de Julho de 2006.

Se o interesse pelas peças de lonesco esmoreceu no final do século $X X$, isso deveu-se sem dúvida às mudanças que aconteceram no mundo e no teatro: a queda do muro de Berlim e o aparente fim da guerra fria declarando a morte das ideologias, o pós-modernismo subsumindo categorias e géneros, quebrando fronteiras e propondo o hibridismo nas artes e nas letras, o teatro pós-dramático emergindo do embate entre teatros realista, épico, absurdo e a performance.

Situemos o texto de lonesco para tentarmos perceber o que pode ele significar ainda hoje para nós e que peso tem na recepção do espectáculo?'.

$\mathrm{Na}$ rádio França Internacional em final de Setembro, Ionesco era referido pelo até há pouco director da Comédie Française como um autor clássico, que mantém as suas qualidades e merece ser revisitado: exemplo disso era precisamente a revigorante encenação de Démarcy-Mota. $\mathrm{Na}$ Cimeira da Francofonia que estava então prestes a decorrer em Bucareste, a já histórica encenação de $A$ Cantora careca em cena há décadas no Théâtre des Noctambules fazia parte da mostra cultural francesa. Claro que lonesco nasceu na Roménia e a França prestava assim jovens e menos jovens encenadores.

É talvez preciso regressar aos idos de 50 para perceber que lonesco, mais do que Beckett, foi centro de polémicas, controvérsia e que os seus textos (de teatro ou sobre teatro) animaram um momento histórico decisivo na configuração do campo teatral francês (do ponto de vista institucional e artístico). Nesse final de década viveu-se o combate entre um teatro entendido como instrumento de acção política e um (anti)teatro de constestação ao teatro de tese, que ainda confiava na sua capacidade de representar e interpretar o mundo. Próximos na manifestação de mal-estar face a uma prática artística reprodutora de valores e ideias de uma burguesia que continuava a dominar os meios de produção cultural, separava-os os modos de expressar esse mal-estar, do ponto de vista tanto artístico, como político.

Refiro-me, é claro, ao tempo em que a França, recuperando do pós-guerra, está na origem de transformações que colocam alguns campos da sua cultura (teatro, literatura, filosofia, sociologia) no centro irradiador de modelos para consumo da elite ocidental. No teatro, viver-se-á a divulgação para cá da "cortina de ferro" do teatro épico e com ele a prevalência da dimensão cénica, isto a par da afirmação de uma dramaturgia que a crítica começa a chamar "do absurdo".

É neste quadro que se inserem os textos de lonesco, especialmente os que subiram à cena entre 1949 e 1953 

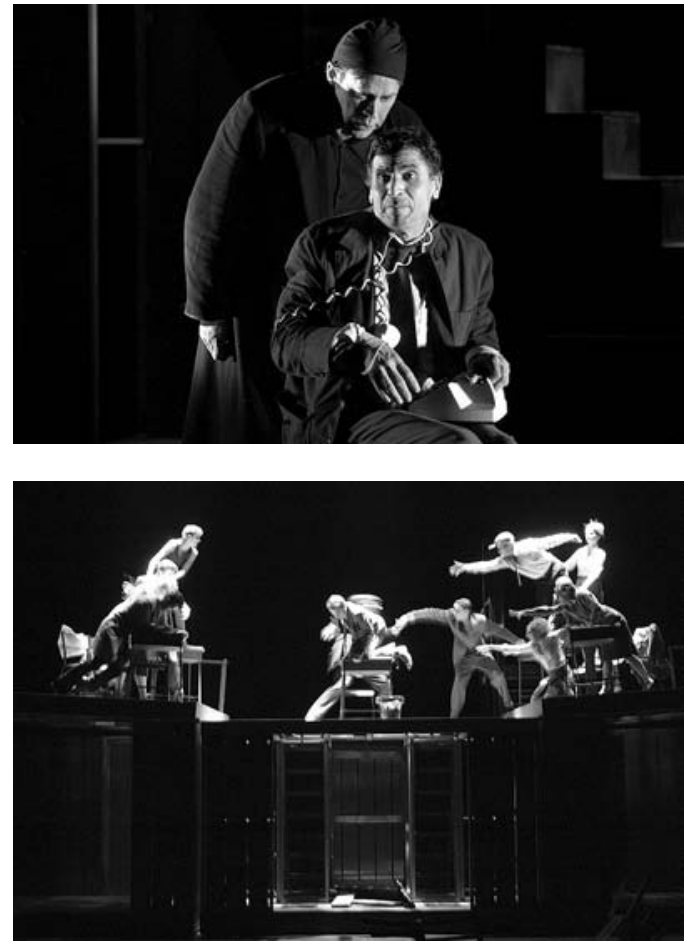

e suscitaram vivas tomadas de posição como as dos críticos ingleses Kenneth Tynan e Philip Toynbee (no Observer, em Junho de 58), testemunhas do entusiasmo de algum público perante a novidade deste teatro, mas também questionadores do que consideravam ser o seu carácter anti-realista ou a sua pretensa autonomia relativamente ao real. Criticado pelo humanismo abstracto das suas peças, lonesco defende-se dizendo que não são as ideologias, nem mesmo o cidadão burguês ou de esquerda, que lhe interessa pôr em cena, mas o simples mortal, o homem comum prisioneiro das suas angústias.

Estes e outros críticos acusaram-no igualmente de transmitir da arte uma visão solipsista e de Ihe negar qualquer função social. A relação entre arte e realidade será na verdade abordada em inúmeras entrevistas ou intervenções públicas por lonesco ${ }^{2}$, através dela se enunciando a questão mais funda da tomada de posição ideológica da obra de arte e do seu autor perante o mundo em que vivemos. Segundo lonesco, a criação artística permite ao autor e ao receptor descobrir aspectos desconhecidos do mundo e da humanidade e não confirmar ou ilustrar ideias préestabelecidas: é expressão da vida e não emanação das ideologias. A única utilidade da arte deveria ser mostrar que há práticas humanas que não servem para nada. A sua defesa da redução da arte à mera expressão de uma visão individual do mundo entrou por isso em fricção com as então dominantes perspectivas existencialista e marxista num quadro político de "guerra fria", sendo que o lonesco crítico dos regimes totalitários e da alienação da sociedade burguesa passou a coexistir com o lonesco nihilista, incapaz de apresentar uma saída para o desconcerto, apesar de, como defendeu, escrever ser uma forma de se explicar.

Em que medida poderia este quadro de referências interessar ao espectador que em Julho deste ano assistiu em Lisboa e no Porto ao espectáculo Rhinocéros? No tempo em que vivemos, onde tudo parece (equi)valer(-se) e as coordenadas ideológicas são remetidas para a margem do agir quotidiano dos individuos como havemos de nos relacionar com este Rhinocéros? Que razão levou DémarcyMota a visitar um texto que exibe a sua "mensagem" de uma forma quase ingénua, que põe em relevo a vulnerabilidade da comunicação linguística quando, passado meio século, as ciências da linguagem, a filosofia, os estudos literários, as tão estimadas ciências da comunicação vulgarizaram e converteram em "natureza" a "estranheza" dessa invenção humana? Por que meios fazer falar, então, este texto de modo a que sejamos sensiveis à actualidade da sua proposta, ou dito de outro modo, para que ele aja sobre nós? Como iluminar mais uma vez o debate que opõe totalitarismo e massificação à liberdade individual sem lhe atribuir uma função didáctica ou exemplar, como tornar visivel a eterna resistência do sujeito à sua absorção/anulação gregária ("Sou o último homem, e assim permanecerei até ao fim") apesar do impulso insustentável para se tornar igual aos outros ("Como sou feio! Maldito aquele que quer conservar a sua originalidade!") sem exacerbar a vertente "existencialista" que o texto também possui? Como interessar o espectador pelo dilema que Bérenger corporiza e que o sentimento que hoje temos da dimensão trágica da nossa alienação parece tornar ridículo?

Creio que Démarcy-Mota e os seus artistas escolheram a via mais inteligente para darem a conhecer um texto e um autor entretanto canonizados: sem subestimarem a sua espessura histórica (apelativa, como disse, para alguns espectadores) e nele a centralidade da linguagem verbal, quer na sua construção (veja-se o carácter explicativo de muitas das cenas e o modo de caracterização das personagens), quer como tópico propriamente dito (a maior ou menor capacidade de as personagens usarem as palavras, a questionação do domínio do raciocínio lógico), conseguiram criar um notável equilibrio entre a presença do texto e a das demais linguagens do teatro, oferecendo um objecto artítico a todos os titulos singular.

São, nesse sentido, de destacar as contribuições dos actores, da cenografia, figurinos e adereços, da iluminação e da banda sonora. Na verdade, o espectador começa por apoiar-se no texto para descobrir a fábula que ele encerra e seguir o desenvolvimento do tópico: a capitulação dos humanos à epidemia de rinocerite.

Todavia, cedo descobre que tem de acompanhar também uma acção desenhada para os corpos dos actores, cujo funcionamento transcende a mera ilustração das situações dramáticas e que ameaça qualquer apreensão literal ou realista do que sobre o palco vai tendo lugar. 0 espectador é, deste modo, impelido a procurar pontos de apoio ora no texto ora na acção cénica, os quais, de facto, nunca colidem ou se anulam, mas, num processo
Rhinocéros, de Eugène lonesco, enc. Emmanuel Démarcy-Mota, Théâtre de la Comédie de Reims, 2006 (Hughes Quester e Serge Maggiani), fot. CTA.

Rhinocéros, de Eugène lonesco, enc. Emmanuel Démarcy-Mota, Théâtre de la Comédie de Reims, 2006 fot. CTA.

Algumas delas reunidas em Notes et contre-notes Paris: Gallimard/idées, 1966. 
de inteligente articulação, produzem uma significação coerente e surpreendentes soluções artísticas.

Desde logo a primeira cena introduz-nos num universo marcado por alguns sinais de estranheza. Reduzindo a pormenorizada e historicamente datada descrição do espaço proposta por lonesco (e que imagens da encenação de Barrault mostram numa concretização tipificada da França dos anos 50) à sua expressão mais simples, o encenador cria um lugar liberto de referência histórica precisa, que sugere aproximações ao tão poderoso imaginário cinematográfico. Para isso concorrem a iluminação e os figurinos ao proporem uma tonalidade única - o cinzento - que deixa toda a cena numa espécie de indistinção e apresenta os actores e as suas personagens como massa anónima apesar da tipificação com que o texto as trata. Quase poderiamos dizer que isso constitui a materialização cénica da predisposição para a aceitação da perda de traços humanos a acontecer mais tarde. Mas o trabalho de iluminação está longe de funcionar como "tradução": é aqui um principio da criação artística.

Por outro lado, ao longo do espectáculo as luzes constituirão, em diálogo com o movimento dos actores, o principal elemento de transfiguração do espaço cénico, o privilegiado ajudante do desenho das cenas, isolandoas e criando zonas a serem mobiladas pela imaginação do espectador, criando gradações de percepção do espaço (entre fundo e boca de cena), dinamizando ou expondo a movimentação dos actores, ora agindo imperceptivelmente sobre a nossa percepção ora, pelo contrário, estabelecendo rupturas surpreendentes. Ao longo do espectáculo o desenho de luzes transfigura espaço e corpos e está em sintonia com a metamorfose de que as palavras nos falam. 0 espectador toma, assim, consciência de algo que tantas vezes Ihe escapa no teatro: que a construção de um espectáculo parte da escuridão total e que se trata de dar a ver e ouvir acções humanas iluminando-as de uma maneira certa.

Que outros aspectos em Rhinocéros foram então banhados por essa luz primordial? Os actores, que são o centro do teatro, de algum teatro pelo menos. Dos que actuaram no espectáculo podemos dizer que foram melhor a significar com o corpo do que com a voz. A uma pouco variada paleta de entoações e registos, demasiado próxima, para ouvidos estrangeiros pelo menos, dos convencionais acentos da língua francesa (o que em certa medida se explica através da opção feita por lonesco pelo registo coloquial) opôs-se uma extraordinariamente expressiva coreografia de movimentos. Démarcy-Mota soube extrair dos corpos dos actores possibilidades significantes inesperadas, quer criando correspondências com a caracterização das personagens feita verbalmente, quer amplificando essa caracterização através da composição de acções e gestos sem qualquer função narrativa, numa sequência de imagens que retiram as situações dramáticas (e o espectáculo) do foro estrito da sátira.
Rompendo com as limitações impostas pelo teatro realista e em consonância com o clima criado pela luz e pela cenografia - de que ainda não falei, mas que coloca em cena um dispositivo monumental em dois andares que cita as propostas de Meyerhold e da biomecânica, promovendo a estilização dos movimentos e a exploração rítmica de fragmentos de gestos e acções - os actores, na emblemática cena passada no escritório (I quadro do II acto), produzem alguns estereotipados gestos de escriturários, num curioso trabalho de "desnaturalização" com o qual o espectáculo pretende mostrar simultaneamente um tipo de relação interhumana (fundamental para entender o desenvolvimento da fábula) e a dimensão alienante de uma prática que a sociedade moderna capitalista inventou. 0 tratamento plástico dos corpos, ao desconstruir a esperada série de acções humanas e a sua imediata interpretação, produz um objecto artístico pleno de estranheza e sedução.

Ao desempenho dos actores, à cenografia e à iluminação é preciso acrescentar a exploração do espaço sonoro que estava já presente na encenação de Barrault através da música concreta de Michel Philippot. Para além das sonoridades previstas pelo texto para sugerir a vibração provocada pela presença cada vez mais numerosa de rinocerontes na cidade e também a reacção humana perante a rinocerite, ouvimos uma composição musical que transmite um clima sonoro e condiciona o modo como captamos o texto, sublinhando, pontuando, segmentando a acção verbal e cénica. As vozes, quando tratadas em conjunto, ganham por vezes uma dimensão instrumental concreta, repercutindo palavras, explorando tons e ritmos, de certa maneira impondo ao espectador um espaço habitado e vivo fora de cena que sublinha o isolamento e a solidão a que, em cena, irá ficar confinado Bérenger. A banda sonora acompanha, deste modo, a crise do sujeito e o angustiado desfecho da acção.

Podemos, pois, afirmar que o teatro de imagens encontra, neste espectáculo, a tradição do teatro de texto, sem complexos nem conflitos, apontando-nos talvez um dos caminhos a trilhar num mundo onde contar e ouvir histórias continua a fazer sentido e obriga a inventar outras formas de o fazer.

Dito isto, um balanço desta recriação do universo de lonesco revela que, longe de se sujeitar à canonizada interpretação do texto e à demonstração da sua possível "utilidade" ou eficácia para representar os males que assolam o mundo contemporâneo, este Rhinocéros oferece uma visão muito singular do dilema sempre presente nas sociedades que prezam a liberdade, dizendo-se consciente, no entanto, de que aquilo que de absurdo a acção encerrava em 1959 deixou de o ser e que, como acontece com a representação de Beckett, embora este em registo trágico, somos cada vez menos humanos embora julguemos continuar a sê-lo. 